\title{
ВПЛИВ ЧИННИКІВ СЕРЦЕВО-СУДИННОГО РИЗИКУ НА РІВНІ ТОЛ-ПОДІБНИХ РЕЦЕПТОРІВ 2 ТА ВАСКУЛОЕНДОТЕЛІАЛЬНОГО ФАКТОРА РОСТУ У ХВОРИХ НА РЕВМАТОЇДНИЙ АРТРИТ
}

Вступ. Серцево-судинна патологія є однією з найбільш частих коморбідностей у пацієнтів 3 рематої̈ним артритом (РА). Активація ангіогенезу в синовіальній оболонці відіграє ключову роль у патогенезі РА. Ця патологія може впливати на перебіг імунозапальних і ангіогенних процесів, у яких беруть участь тол-подібні рецептори 2 (TLR2) та васкулоендотеліальний фрактор росту (VEGF).

Мета дослідження - встановити вплив чинників серцево-судинного ризику на рівні тол-подібних рецепторів 2 та васкулоендотеліального фрактора росту в сироватці крові хворих на ревматоїдний apmpum.

Методи дослідження. Обстежено 67 хворих на РА (73,1 \% жінок) середнім віком $(45,20 \pm 8,75)$ року та 25 практично здорових осіб контрольної групи. Діагноз РА встановлювали за критеріями ACR/EULAR 2010. Рівні TLR2 ma VEGF у сироватці крові визначали імуноферментним методом (Cloud-Clone Corp., США). Дослідження проводили з дотриманням біоетичних норм. Статистичну обробку результатів здійснювали в пакеті STATISTICA 6,0.

Результати й обговорення. У хворих на PA рівні TLR2 ma VEGF були достовірно більшими (у 2,78 i 2,69 раза, p<0,001), ніж в осіб контрольної групи, у хворих з індексом DAS28-ШОE >5,1 - вищими (в 1,31,4 раза), ніж у пацієнтів з помірною активністю захворювання (індекс DAS28-ШOE 3,2-5,1). Більш значуще зростання рівня TLR2 відмічали в серопозитивних за антитілами до цитрулінованого циклічного пептиду пацієнтів. Підвищення рівнів TLR2 i VEGF у хворих на PA асоціювалось із супутньою артеріальною гіпертензією та ожирінням і не залежало від віку, статі, дисліпідемії, тютюнокуріння.

Висновки. У хворих на PA відзначають збільшення рівнів TLR2 та VEGF у сироватці крові порівняно з практично здоровими особами. Зростання рівня TLR2 сильніше асоціюється з високою активністю захворювання і серопозитивністю за антитілами до цитрулінованого циклічного пептиду, тоді як збільшення рівня VEGF - з коморбідною артеріальною гіпертензією та високим індексом маси тіла.

КЛЮчОВІ СЛОВІ: ревматоїдний артрит; тол-подібні рецептори 2; васкулоендотеліальний фрактор росту; чинники серцево-судинного ризику.

ВСТУП. Кардіоваскулярні захворювання посідають перше місце в структурі коморбідності та смертності хворих на ревматоїдний артрит (РA) [1]. За РА створюється несприятливий імунозапальний патерн, який прискорює розвиток ендотеліальної дисорункціїта атеросклеротичного ураження судин [2, 3]. У результаті хронічного автоімунного запального процесу, асоційованого з дисбалансом у системі клітинного імунітету, гіперпродукуванням С-реактивного протеїну, прозапальних цитокінів, антитіл до циклічних цитрулінованих пептидів, відбувається імунозапальна активація ендотелію, порушується продукування вазоактивних медіаторів, прискорюються ремоделювання судин та утворення атеросклеротичних бляшок [2, 4]. 3 іншого боку, серцево-

(с) Ю. С. Сегеда, І. П. Кувікова, Л. В. Мороз, О. І. Штатько, О. В. Тертишна, 2020. судинна коморбідність через дисрегуляцію експресії прозапальних та проангіогенних медіаторів потенційно може погіршувати перебіг PA. Зокрема, в ряді досліджень засвідчено підвищення рівня васкулоендотеліального орактора росту (VEGF) у сироватці крові пацієнтів з артеріальною гіпертензією, ожирінням, цукровим діабетом [5-7]. Нещодавно було показано зв'язок між механізмами розвитку артеріальної гіпертензії та експресією тол-подібних рецепторів різних типів (особливо TLR2, TLR4), які активують механізми запалення та ангіогенезу [8-10]. Тому визначення впливу чинників серцево-судинного ризику на продукування TLR2 та VEGF у хворих на РА залишається актуальним.

Мета дослідження - встановити вплив чинників серцево-судинного ризику на рівні тол-подібних рецепторів 2 та васкулоендотеліального 
фактора росту в сироватці крові хворих на ревматоїдний артрит.

МЕТОДИ ДОСЛІДЖЕННЯ. Обстежено 67 Хворих на РА, 3 них 18 (26,9\%) чоловіків та 49 $(73,1 \%)$ жінок, середнім віком $(45,20 \pm 8,75)$ року і з тривалістю захворювання $(8,64 \pm 5,98)$ року, які перебували на стаціонарному лікуванні у ревматологічному відділенні Науково-дослідного інституту реабілітації інвалідів Вінницького національного медичного університету. Контрольну групу становили 25 практично здорових осіб $(72,0 \%$ жінок) середнім віком $(44,50 \pm 8,42)$ року. Дослідження проведено 3 дотриманням біоетичних норм відповідно до положень ВОО3, Гельсінської декларації Генеральної асамблеї Всесвітньої медичної асоціації (1989), Конвенції Ради Європи про права людини та біомедицину (1977), діючих законів України.

Діагноз РА встановлювали за міжнародними класифрікаційними критеріями ACR/EULAR 2010. Активність захворювання оцінювали за індексом DAS28-шOE, серологічний варіант - за рівнем антитіл до цитрулінованого циклічного пептиду (АЦЦП). У дослідження було включено 44 (65,7 \%) хворих 3 помірною активністю РА (DAS28-ШOE 3,2-5,1) та 23 (34,3 \%) пацієнти 3 високою активністю захворювання (DAS28-ШОЕ $>5,1) ; 56$ (83,6 \%) хворих були серопозитивними за АЦЦП, у 58 (86,6 \%) пацієнтів виявлено IIIII рентгенологічну стадію ураження суглобів. Хворі на РА отримували стандартну хворобомодифікуючу терапію, якої не змінювали протягом останніх 4-х тижнів (метотрексат >10 мг/тиждень, стабільні дози пероральних нестероїдних протизапальних препаратів, глюкокортикоїдів).

У хворих на РА, яких було включено у дослідження, виявлено такі чинники серцевосудинного ризику, як: артеріальна гіпертензія II стадії 1-2 ступеня - 19 (28,4 \%) осіб; ожиріння (індекс маси тіла $\geq 30$ кг/м²) - 10 (14,9\%) осіб; атерогенна дисліпідемія (ліпопротеїни низької щільності >3 ммоль/л) - 25 (37,3\%) осіб; активне тютюнокуріння - 12 (17,9 \%) осіб. У дослідження не залучали пацієнтів із супутнім цукровим діабетом, морбідним ожирінням (індекс маси тіла $>40$ кг $\left./ \mathrm{M}^{2}\right)$, тяжкими і некомпенсованими станами.

Кров забирали 3 ліктьової вени вранці натщесерце за допомогою вакуумних систем Vacuette (Greiner Bio-One). Сироватку отримували шляхом центрифугування цільної крові при 1500 g упродовж 20 хв при 18-22 ${ }^{\circ} \mathrm{C}$. Рівні TLR2 та VEGF у сироватці крові визначали методом ELISA за допомогою наборів "Enzyme-linked Immunosorbent Assay Kit For Toll Like Receptor 2 (TLR2)" (Cloud-Clone Corp., США, SEA663Hu) та
"Enzyme-linked Immunosorbent Assay Kit For Vascular Endothelial Growth Factor A (VEGFA)" (Cloud-Clone Corp., США, SEA143Нu) відповідно до інструкції фрірми-виробника на автоматичному аналізаторі STAT FAX 303/PLUS (США).

Статистичну обробку результатів проводили в пакеті STATISTICA 6,0 (ліцензійний № AXXR910A374605FA). Для оцінки різниці між групами використовували t-критерій Стьюдента (при нормальному розподілі) або U-критерій Манна - Уїтні (про розподілі, що відхилявся від нормального). Для оцінки зв'язку між показниками застосовували коефріцієнт кореляції Пірсона. Нормальність розподілу оцінювали за критерієм Шапіро - Уїлка. Достовірною вважали різницю при $\mathrm{p}<0,05$.

РЕЗУЛЬТАТИЙОБГОВОРЕННЯ.У УРРКТИЧНО здорових осіб контрольної групи рівень TLR2 у сироватці крові коливався в діапазоні 101450 нг/л (min-max) і в середньому становив 161,6 пг/мл (табл. 1), рівень VEGF коливався в діапазоні 116-372 пг/л (min-max) та в середньому становив 230 пг/мл.

У хворих на PA рівні TLR2 та VEGF були достовірно більшими (у 2,78 і 2,69 раза, p<0,001), ніж в осіб контрольної групи. При аналізі рівнів TLR2 та VEGF залежно від клініко-демограсрічних характеристик не виявлено статистично значущих відмінностей залежно від статі й віку пацієнтів з РА, а також тривалості захворювання. Водночас у хворих на РА з високою активністю захворювання (DAS28-ШOE $>5,1$ ) реєстрували достовірно більші (в 1,39 й 1,25 раза) рівні TLR2 та VEGF, ніж у пацієнтів з помірною активністю захворювання. У хворих із серопотивним РА рівень TLR2 був достовірно вищим (в 1,32 раза), ніж у пацієнтів із серонегативним РА. Рівень VEGF мав тенденцію до зростання за наявності високих титрів АЦЦП.

Підвищення рівнів TLR2 та VEGF у хворих на РА також асоціювалось 3 наявністю чинників серцево-судинного ризику (табл. 2). Так, у хворих на PA з артеріальною гіпертензією рівні TLR2 та VEGF були більшими (в 1,33 й 1,41 раза), ніж у пацієнтів без неї. У хворих з індексом маси тіла $\geq 30$ кг/м² відзначали статистично значуще зростання рівня VEGF (в 1,27 раза), тоді як рівень TLR2 мав тенденцію до підвищення. Дисліпідемія і тютюнокуріння в пацієнтів з РА асоціювались зі слабкою тенденцією до збільшення рівнів TLR2 та VEGF у сироватці крові.

Кореляційний аналіз засвідчив достовірний прямий зв'язок між рівнями TLR2 та VEGF у сироватці крові ( $r=0,58, p<0,001)$. Рівні TLR2 та VEGF прямо корелювали з рівнем C-реактивного протеїну $(r=0,54, p<0,001$ і $r=0,48, p<0,01)$ та 
Таблиця 1 - Рівні тол-подібних рецепторів 2 та васкулоендотеліального фрактора росту

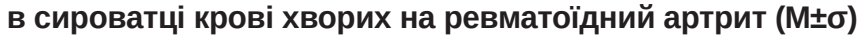

\begin{tabular}{|c|c|c|c|c|}
\hline Характеристика групи & TLR2, пг/мл & VEGF, пг/мл & $\mathrm{p}_{1}$ & $\mathrm{p}_{2}$ \\
\hline Контроль $(\mathrm{n}=25)$ & $161,6 \pm 73,6$ & $230,7 \pm 70,2$ & \multirow[t]{2}{*}{$<0,001$} & \multirow[t]{2}{*}{$<0,001$} \\
\hline Хворі на PA (n=67) & $450,2 \pm 144,3$ & $620,1 \pm 177,8$ & & \\
\hline \multicolumn{5}{|c|}{ Розподіл хворих на РА за статтю } \\
\hline Жінки $(\mathrm{n}=49)$ & $439,7 \pm 154,4$ & $617,8 \pm 184,8$ & \multirow[t]{2}{*}{$>0,05$} & \multirow[t]{2}{*}{$>0,05$} \\
\hline Чоловіки $(\mathrm{n}=18)$ & $478,0 \pm 111,6$ & $626,7 \pm 162,0$ & & \\
\hline \multicolumn{5}{|c|}{ Розподіл хворих на РА за віком } \\
\hline Вік $\leq 44$ років $(n=38)$ & $441,2 \pm 168,5$ & $622,4 \pm 204,0$ & \multirow[t]{2}{*}{$>0,05$} & \multirow[t]{2}{*}{$>0,05$} \\
\hline Вік 44-60 років $(n=29)$ & $461,5 \pm 106,5$ & $617,2 \pm 139,9$ & & \\
\hline \multicolumn{5}{|c|}{ Розподіл хворих на РА за тривалістю захворювання } \\
\hline Тривалість РA $\leq 5$ років $(\mathrm{n}=26)$ & $415,0 \pm 170,5$ & $602,3 \pm 210,7$ & \multirow[t]{2}{*}{$>0,05$} & \multirow[t]{2}{*}{$>0,05$} \\
\hline Тривалість РА >5 років $(\mathrm{n}=41)$ & $472,2 \pm 122,1$ & $631,5 \pm 155,2$ & & \\
\hline \multicolumn{5}{|c|}{ Розподіл хворих на РА за активністю захворювання } \\
\hline DAS28-ШOE $\leq 5,1(n=44)$ & $396,6 \pm 133,3$ & $570,7 \pm 148,2$ & \multirow[t]{2}{*}{$<0,001$} & \multirow[t]{2}{*}{$<0,01$} \\
\hline DAS28-ШOE >5,1 (n=23) & $552,1 \pm 105,8$ & $714,8 \pm 194,2$ & & \\
\hline \multicolumn{5}{|c|}{ Розподіл хворих на РА за серологічним варіантом захворювання } \\
\hline Серопозитивні за АЦЦП (n=56) & $470,6 \pm 139,3$ & $634,4 \pm 177,9$ & \multirow[t]{2}{*}{$<0,05$} & \multirow[t]{2}{*}{$>0,05$} \\
\hline Серонегативні за АЦЦП (n=11) & $355,6 \pm 133,7$ & $555,0 \pm 169,7$ & & \\
\hline
\end{tabular}

Примітка. Тут і в таблиці 2: $p_{1}$ - достовірність відмінностей за рівнем TLR2; $p_{2}$ - достовірність відмінностей за рівнем VEGF.

Таблиця 2 - Рівні тол-подібних рецепторів 2 та васкулоендотеліального фактора росту

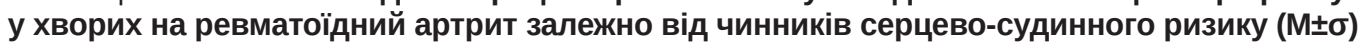

\begin{tabular}{|c|c|c|c|c|}
\hline Характеристика групи & TLR2, пг/мл & VEGF, пг/мл & $\mathrm{p}_{1}$ & $\mathrm{p}_{2}$ \\
\hline \multicolumn{5}{|c|}{ Розподіл хворих на РА за артеріальною гіпертензією } \\
\hline Хворі на РА без артеріальної гіпертензії (n=48) & $414,6 \pm 138,0$ & $525,1 \pm 159,3$ & \multirow[t]{2}{*}{$<0,01$} & \multirow[t]{2}{*}{$<0,01$} \\
\hline Хворі на РА з артеріальною гіпертензією (n=19) & $554,1 \pm 111,3$ & $741,9 \pm 177,5$ & & \\
\hline \multicolumn{5}{|c|}{ Розподіл хворих на РА за індексом маси тіла } \\
\hline Індекс маси тіла <30 кг/м² (n=57) & $439,6 \pm 153,9$ & $573,2 \pm 157,0$ & \multirow[t]{2}{*}{$>0,05$} & \multirow[t]{2}{*}{$<0,01$} \\
\hline Індекс маси тіла $\geq 30$ кг/м² $(\mathrm{n}=10)$ & $497,8 \pm 91,0$ & $728,7 \pm 148,1$ & & \\
\hline \multicolumn{5}{|c|}{ Розподіл хворих на РА за дисліпідемією } \\
\hline Без дисліпідемії (n=42) & $430,7 \pm 166,8$ & $614,4 \pm 198,0$ & \multirow[t]{2}{*}{$>0,05$} & \multirow[t]{2}{*}{$>0,05$} \\
\hline 3 дисліпідемією (n=25) & $480,5 \pm 94,4$ & $629,2 \pm 143,7$ & & \\
\hline \multicolumn{5}{|c|}{ Розподіл хворих на РА за тютюнокурінням } \\
\hline Некурці (n=55) & $438,2 \pm 150,3$ & $612,2 \pm 179,1$ & \multirow[t]{2}{*}{$>0,05$} & \multirow[t]{2}{*}{$>0,05$} \\
\hline Активні курці (n=12) & $501,5 \pm 103,9$ & $647,5 \pm 177,1$ & & \\
\hline
\end{tabular}

показником активності PA - індексом DAS28ШОЕ ( $r=0,62, p<0,001$ i r=0,46, p<0,01 відповідно). Встановлено достовірний зв'язок середньої сили між рівнем VEGF та індексом маси тіла $(r=0,36$, $\mathrm{p}<0,05)$ і систолічним артеріальним тиском $(r=0,42, p<0,01)$, натомість статистично значущого зв'язку рівня TLR2 із вказаними параметрами не виявлено.

Результати, які ми отримали, узгоджуються з результатами досліджень інших авторів, які відзначали, що підвищення рівня VEGF y сироватці крові хворих на РА не залежало від віку і статі [11] й тісно асоціювалось з активністю запального процесу $[12,13]$. Виявлена закономірність щодо підвищення рівня TLR2 у сироватці крові пацієнтів з РА на тлі серцево- судинної коморбідності відповідає результатам дослідження М. Houssen та ін. (2014), які встановили асоціацію між кардіоваскулярною дисфункцією і зростанням рівня розчинних TLR2 у сироватці крові хворих на системний червоний вовчак [14].

ВИСНОВКИ. У хворих на РА відзначають збільшення рівнів TLR2 та VEGF у сироватці крові порівняно з практично здоровими особами. Зростання рівня TLR2 сильніше асоціюється 3 високою активністю захворювання і серопозитивністю за АЦЦП, ніж VEGF. Натомість збільшення рівня VEGF сильніше асоціюється із супутньою артеріальною гіпертензією та високим індексом маси тіла, ніж рівень TLR2. 


\section{СПИСОК ЛІТЕРАТУРИ}

1. Knowledge and perception of cardiovascular disease risk among patients with rheumatoid arthritis / S. Boo, H. Oh, E. S. Froelicher, C. H. Suh // PLoS One. 2017. - 12, No. 4. - e0176291. doi: 10.1371/journal. pone.0176291.

2. Liao K. P. Cardiovascular disease in patients with rheumatoid arthritis / K. P. Liao // Trends Cardiovasc. Med. - 2017. - 27, No. 2. - P. 136-140. doi: 10.1016/j. tcm.2016.07.006.

3. Recognition and control of hypertension, diabetes, and dyslipidemia in patients with rheumatoid arthritis / L. L. Castro, C. C. D. Lanna, M. P. Rocha [et al.] // Rheumatol. Int. - 2018. - 38, No. 8. - P.1437-1442. doi: 10.1007/s00296-018-4084-3.

4. Rheumatoid arthritis, anti-cyclic citrullinated peptide positivity, and cardiovascular disease risk in the women's health initiative / R. H. Mackey, L. H. Kuller, K. D. Deane [et al.] // Arthritis Rheumatol. - 2015. - 67, No. 9. - P. 2311-2322. doi: 10.1002/art.39198.

5. Мисниченко О. В. Рівні ангіопоетину-2 і васкулоендотеліального фрактора росту в крові у хворих на гіпертонічну хворобу з абдомінальним ожирінням в динаміці 12-тижневої антигіпертензивної і гіполіпідемічної терапії / О. В. Мисниченко // Експерим. і клініч. медицина. - 2016. - 70, № 1. - С. 84-88.

6. Могильницька Л. А. Концентрація васкулоендотеліального фактору росту в сироватці крові хворих 3 артеріальною гіпертензією, що супроводжується цукровим діабетом 2-го типу, ожирінням / Л. А. Могильницька // Вісн. проблем біології і медицини. - 2017. - 3, № 141. - С. 158-163.

7. Overweight and obesity versus concentrations of VEGF-A, sVEGFR-1, and sVEGFR-2 in plasma of patients with lower limb chronic ischemia / R. Wieczór, A.M. Wieczór, G. Gadomska [et al.] // J. Zhejiang Univ. Sci. B. - 2016. - 17, No. 11. - P. 842-849. doi:10.1631/ jzus.B1600009

\section{REFERENCES}

1. Boo, S., Oh, H., Froelicher E.S., \& Suh, C.H. (2017) Knowledge and perception of cardiovascular disease risk among patients with rheumatoid arthritis. PLoS One, 12 (4):e0176291. doi: 10.1371/journal.pone.0176291. [PubMed]

2. Liao, K.P. (2017) Cardiovascular disease in patients with rheumatoid arthritis. Trends Cardiovasc. Med., 27 (2), 136-140. doi: 10.1016/j.tcm.2016.07.006. [PubMed]

3. Castro, L.L., Lanna, C.C.D., Rocha, M.P., Ribeiro, A.L.P., \& Telles, R.W. (2018). Recognition and control of hypertension, diabetes, and dyslipidemia in patients with rheumatoid arthritis. Rheumatol. Int., 38 (8), 14371442. doi: 10.1007/s00296-018-4084-3.

4. Mackey, R.H., Kuller, L.H., Deane, K.D., Walitt, B.T., Chang, Y.F., Holers, V.M., Robinson, W.H., ... \& Moreland, L.W. (2015) Rheumatoid arthritis, anti-cyclic citrullinated peptide positivity, and cardiovascular disease risk in the women's health initiative. Arthritis Rheumatol., 67 (9), 2311-2322. doi: 10.1002/art.39198.
8. Regulation of angiogenesis, mural cell recruitment and adventitial macrophage behavior by Toll-like receptors / A. C. Aplin, G. Ligresti, E. Fogel [et al.] // Angiogenesis. - 2014. - 17, No. 1. - P. 147-161. doi: 10.1007/ s10456-013-9384-3.

9. Toll-like receptors and damage-associated molecular patterns: novel links between inflammation and hypertension / C. G. McCarthy, S. Goulopoulou, C. F. Wenceslau [et al.] // Am. J. Physiol. Heart Circ. Physiol. 2014. - 306, No. 2. - P. 184-196. doi:10.1152/ ajpheart.00328.2013.

10. DNA methylation of candidate genes (ACE II, IFN-y, AGTR 1, CKG, ADD1, SCNN1B and TLR2) in essential hypertension: a systematic review and quantitative evidence synthesis / L. Jr. Holmes, A. Lim, C. R. Comeaux [et al.] // Int. J. Environ. Res. Public. Health. - 2019. - 16, No. 23. - E4829. doi: 10.3390/ ijerph16234829.

11. Circulating VEGF as a biological marker in patients with rheumatoid arthritis? Preanalytical and biological variability in healthy persons and in patients / M. L. Hetlanda, J. Christensen, T. Lottenburgerc [et al.] // Disease Markers. - 2008. - 24. - P.1-10.

12. Воронков Л. Г.Вплив судинногоендотеліального фрактора росту на клініко-лабораторно-інструментальні показники у хворих на ревматоїдний артрит / Л. Г. Воронков, О. Б. Комарова // Укр. ревматол. журн. 2014. - 57, № 3. - С. 91-93.

13. Lee Y. H. Correlation between circulating VEGF levels and disease activity in rheumatoid arthritis: a metaanalysis / Y. H. Lee, S. C. Bae // Z. Rheumatol. - 2018. 77, No 3. - P. 240-248. doi: 10.1007/s00393-016-0229-5.

14. Houssen M. Serum soluble toll-like receptor 2: a novel biomarker for systemic lupus erythematosus disease activity and lupus-related cardiovascular dysfunction // International Journal of Rheumatic Diseases. 2014. - 19, No. 7. - P. 685-692.

5. Mysnychenko, O.V. (2016). Rivni anhiopoetynu-2 i vaskuloendotelialnoho faktora rostu $v$ krovi u khvorykh na hipertonichnu khvorobu z abdominalnym ozhyrinniam v dynamitsi 12-tyzhnevoi antyhipertenzyvnoi i hipolipidemichnoi terapii [Levels of angiopoietin-2 and vascular endothelial growth factor in the blood of patients with essential hypertension and abdominal obesity after 12 weeks of combined antihypertensive and lipid-lowering treatment]. Eksperymentalna i klinichna medytsyna Experimental and Clinical Medicine, 70 (1), 84-88 [in Ukrainian].

6. Mohylnytska, L.A. (2017) Kontsentratsiia vaskuloendotelialnoho faktoru rostu v syrovattsi krovi khvorykh z arterialnoiu hipertenziieiu, shcho suprovodzhuietsia tsukrovym diabetom 2-ho typu, ozhyrinniam [Serum level of vegf in arterial hypertension with type 2 diabetes, obesity]. Visnyk problem biolohii i medytsyny - Bulletin of Problems of Biology and Medicine, 3 (141), 158-163 [in Ukrainian]. 
7. Wieczór, R., Wieczór, A.M., Gadomska, G., Stankowska, K., Fabisiak, J., Suppan, K., Pulkowski, G., .... \& Rość, D. (2016). Overweight and obesity versus concentrations of VEGF-A, sVEGFR-1, and sVEGFR-2 in plasma of patients with lower limb chronic ischemia. J. Zhejiang Univ. Sci. B., 17 (11), 842-849. doi:10.1631/ jzus.B1600009.

8. Aplin, A.C., Ligresti, G., Fogel, E., Zorzi, P., Smith, K., \& Nicosia, R.F. (2014). Regulation of angiogenesis, mural cell recruitment and adventitial macrophage behavior by Toll-like receptors. Angiogenesis. , 17(1):147161. doi: 10.1007/s10456-013-9384-3.

9. McCarthy, C.G., Goulopoulou, S., Wenceslau, C.F., Spitler, K., Matsumoto, T., \& Webb, R.C. (2014). Toll-like receptors and damage-associated molecular patterns: novel links between inflammation and hypertension. Am. J. Physiol. Heart Circ. Physiol., 306 (2), 184-196. doi:10.1152/ajpheart.00328.2013.

10. Holmes, L.Jr., Lim, A., \& Comeaux, C.R. (2019). DNA methylation of candidate genes (ACE II, IFN-y, AGTR 1, CKG, ADD1, SCNN1B and TLR2) in essential hypertension: a systematic review and quantitative evidence synthesis. Int. J. Environ. Res. Public. Health, 16 (23). E4829. doi: 10.3390/ijerph16234829.
11. Hetlanda, M.L., Christensenb, J., Lottenburgerc, T., Johansend, J.S., Svendsen, M. N., Hørslev-Petersenc, K., Nielsene, L. \& Nielsen, H.J. (2008). Circulating VEGF as a biological marker in patients with rheumatoid arthritis? Preanalytical and biological variability in healthy persons and in patients. Disease Markers, 24, 1-10.

12. Voronkov, L.H., \& Komarova, E.B. (2014). Vplyv sudynnoho endotelialnoho faktora rostu na klinikolaboratorno-instrumentalni pokaznyky u khvorykh na revmatoidnyi artryt [Influence of vascular endothelial growth factor on the clinical-laboratory-instrumental parametrs in patients with rheumatoid arthritis]. Ukr. Revm. Zhurn. - Ukrainian Rheumatological Journal, 57 (3), 91-93 [in Ukrainian].

13. Lee, Y.H., \& Bae, S.C. (2018). Correlation between circulating VEGF levels and disease activity in rheumatoid arthritis: a meta-analysis. Z. Rheumatol., 77 (3), 240-248. doi: 10.1007/s00393-016-0229-5.

14. Houssen, M., El-Mahdy, R., \& Shahin, D. (2014). Serum soluble toll-like receptor 2: a novel biomarker for systemic lupus erythematosus disease activity and lupusrelated cardiovascular dysfunction. International Journal of Rheumatic Diseases, 19 (7), 685-692.

Ю. С. Сегеда, И. П. Кувикова, Л. В. Мороз, Е. И. Штатько, Е. В. Тертишная ВИННИЦКИЙ НАЦИОНАЛЬНЫЙ МЕДИЦИНСКИЙ УНИВЕРСИТЕТ ИМЕНИ Н. И. ПИРОГОВА

\section{ВЛИЯНИЕ ФАКТОРОВ СЕРДЕЧНО-СОСУДИСТОГО РИСКА НА УРОВНИ ТОЛЛ-ПОДОБНЫХ РЕЦЕПТОРОВ 2 И ВАСКУЛОЭНДОТЕЛИАЛЬНОГО ФАКТОРА РОСТА У БОЛЬНЫХ РЕВМАТОИДНЫМ АРТРИТОМ}

\section{Резюме}

Вступление. Сердечно-сосудистая патология является одной из наиболее частых коморбидностей у пациентов с ревматоидным артритом (PA). Активация ангиогенеза в синовиальной оболочке играет ключевую роль в патогенезе РА. Эта патология может влиять на течение иммуновоспалительных и ангиогенных процессов, в которых принимают участие толл-подобные рецепторы 2 (TLR2) и васкулоэндотелиальный фрактор роста (VEGF).

Цель исследования - установить влияние фракторов сердечно-сосудистого риска на уровни толлподобных рецепторов 2 и васкулоэндотелиального фрактора роста в сыворотке крови больных ревматоидным артоитом.

Методы исследования. Обследовано 67 больных РА (73,1 \% женщин) в среднем возрасте $(45,20 \pm 8,75)$ лет и 25 практически здоровых лиц контрольной группы. Диагноз РА устанавливали по критериям ACR/EULAR 2010. Уровни TLR2 и VEGF в сыворотке крови определяли иммуноферментным методом (Cloud-Clone Corp., США). Исследование проводили с соблюдением биоэтических норм. Cтатистическую обработку результатов осуществляли в пакете STATISTICA 6.0.

Результаты и обсуждение. У больных PA уровни TLR2 и VEGF были достоверно больше (в 2,78 u 2,69 раза, p<0,001), чем у лиц контрольной группы, у больных с индексом DAS28-COЭ >5,1 - выше (в 1,3-1,4 раза), чем у пациентов с умеренной активностью заболевания (индекс DAS28-COЭ 3,2-5,1). Более значимое возрастание уровня TLR2 отмечали у серопозитивных по антителам к цитруллинированному циклическому пептиду пациентов. Повышение уровней TLR2 и VEGF у больных PA ассоциировалось $c$ сопутствующей артериальной гипертензией и ожирением и не зависело от возраста, пола, дислипидемии, табакокурения.

Выводы. У больных PA отмечают увеличение уровней TLR2 и VEGF в сыворотке крови по сравнению с практически здоровыми лицами. Возрастание уровня TLR2 более сильно ассоциируется с высокой 
активностью заболевания и серопозитивностью по антителам к цитруллинированному циклическому пептиду, в то время как увеличение уровня VEGF-c коморбидной артериальной гипертензией и высоким индексом массы тела.

КЛЮЧЕВЫЕ СЛОВА: ревматоидный артрит; толл-подобные рецепторы 2; васкулоэндотелиальный фрактор роста; фракторы сердечно-сосудистого риска.

Y. S. Seheda, I. P. Kuvikova, L. V. Moroz, O. I. Shtatko, O. V. Tertyshna NATIONAL PIROGOV MEMORIAL MEDICAL UNIVERSITY, VINNYTSIA

\section{INFLUENCE OF CARDIOVASCULAR RISK FACTORS ON THE LEVELS OF TOLL-LIKE RECEPTORS 2 AND VASCULOENDOTHELIAL GROWTH FACTOR IN PATIENTS WITH RHEUMATOID ARTHRITIS}

Summary
Introduction. Rheumatoid arthritis (RA) is a disease with high prevalence and disability rates. Cardiovascular pathology is one of the most frequent comorbid pathologies in RA patients. Activation of angiogenesis in the synovium plays a key role in pathogenetic mechanism of RA. Cardiovascular pathology can influence on inflammatory and angiogenic processes with the participation of toll-like receptors 2 (TLR2) and vasculoendothelial growth factor (VEGF).

The aim of the study - to determine the effect of cardiovascular risk factors on the level of TLR2 and VEGF in the blood of RA patients.

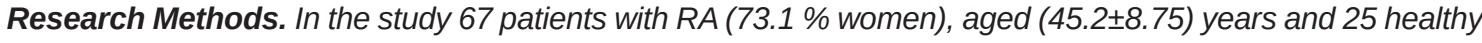
controls age-matched were enrolled. The diagnosis of RA was established by ACR/EULAR criteria 2010. Serum TLR2 and VEGF levels were determined by enzyme immunoassay (Cloud-Clone Corp., USA). The study was conducted in compliance with bioethical standards. Statistical processing of the results was performed in the STATISTICA 6.0 package.

Results and Discussion. In RA patients, TLR2 and VEGF levels were significantly 2.78 and 2.69-times higher, respectively $(p<0.001)$ than in the control group. In patients with DAS28-ESR $>5.1, T L R 2$ and VEGF levels were higher (1.3-1.4 times) than in patients with moderate disease activity (DAS28-ESR 3.2-5.1). Among the seropositive by ACCP subjects, levels of TLR2 were significantly higher. Increased levels of TLR2 and VEGF in RA patients were associated with concomitant hypertension and obesity, though no connection with age, gender, dyslipidemia, and smoking was found.

Conclusions. Among RA patients serum levels of TLR2 and VEGF were higher, compared to the control. Increasing of TLR2 level associated with seropositivity by ACCP and high disease activity, and VEGF elevation associated with comorbid arterial hypertension and high body mass index.

KEY WORDS: rheumatoid arthritis; toll-like receptors 2; vasculoendothelial growth factor; cardiovascular risk factors.

Отримано 22.01.20

Адреса для листування: Ю. С. Сегеда, НДІ реабілітації осіб з інвалідністю Вінницького національного медичного університету імені М. І. Пирогова, Хмельницьке шосе, 104, Вінниця, 21000, Україна, e-mail: iuliia.segeda@gmail.com. 